\title{
Habitat suitability assessment of the rare perennial plant Armeria arenaria (Pers.) Schult. (Plumbaginaceae) along the French Mediterranean coastline
}

\author{
Alex Baumel, Sami Youssef, George Ongamo \& Frédéric Médail
}

\begin{abstract}
BAUMEL, A., S. YOUSSEF, G. ONGAMO \& F. MÉDAIL (2013). Habitat suitability assessment of the rare perennial plant Armeria arenaria (Pers.) (Plumbaginaceae) Schult. along the French Mediterranean coastline. Candollea 68: 221-228. In English, English and French abstracts.

A major challenge in conservation biology is to identify the factors driving abundance and demographic regeneration of rare species populations. We assess habitat suitability within a protected area for Armeria arenaria (Pers.) Schult. (Plumbaginaceae), a small perennial polycarpic plant and keystone species of a threatened plant community on the rocky crystalline coastline of South-East France. The factors associated with the occurrence and abundance of adult plants and juveniles of this species were investigated by an "Outlier Mean Index analysis" (OMI). A second census was conducted three years later to test the reliability of inferences about habitat suitability. The results underline the importance of fine scale habitat heterogeneity to understand the variation of abundance. Moreover only a portion of the habitat of Armeria arenaria is suitable for regeneration, underlying the necessity to consider both abundance and regeneration to set conservation and management priorities.
\end{abstract}

\section{Key-words}

PLUMBAGINACEAE - Arenaria - French Mediterranean coastline - Conservation - Ecology - Protected area - Multivariate analysis

\section{Résumé}

BAUMEL, A., S. YOUSSEF, G. ONGAMO \& F. MÉDAIL (2013). Evaluation de la qualité d'habitat de l'espèce pérenne rare Armeria arenaria (Plumbaginaceae) sur la côte méditerranéenne française. Candollea 68: 221228. En anglais, résumés anglais et français.

L'un des défis importants de la biologie de la conservation est d'identifier les facteurs contrôlant l'abondance et la régénération démographique des populations d'espèces rares. Au sein d'une aire protégée, nous avons évalué la qualité d'habitat pour Armeria arenaria (Pers.) Schult. (Plumbaginaceae), une plante polycarpique, pérenne, de petite taille, et espèce clé d'une communauté végétale menacée du littoral cristallin du Sud Est de la France. Les facteurs écologiques associés à la présence et à l'abondance des plantes adultes et juvéniles de cette espèce ont été analysés par une analyse «Outlier Mean Index» (OMI). Un deuxième recensement a été mené trois ans plus tard pour tester la robustesse de nos déductions sur la qualité d'habitat. Les résultats soulignent l'importance de l'hétérogénéité à échelle fine de l'habitat pour comprendre la variation d'abondance. De plus seulement une partie des habitats d'Armeria arenaria est adéquate pour la régénération, soulignant la nécessité de tenir compte de l'abondance et de la régénération pour établir des priorités de conservation et de gestion.

\footnotetext{
Addresses of the authors: AB, FM: Institut Méditerranéen de Biodiversité et d'Ecologie (IMBE, UMR CNRS 7263), Aix-Marseille Université, Technopôle de l'Environnement Arbois-Méditerranée, BP 80, 13545 Aix-en-Provence cedex 04, France.

SY: Faculty of Agriculture and Forestry, University of Duhok, Kurdistan Region, Iraq

GO: School of Biological Science, College of Physical and Biological Sciences (Chiromo Campus), University of Nairobi, P. O. Box 30197, Nairobi, Kenya.
} 


\section{Introduction}

Plant survival and population fitness vary according to various factors within the range of a species. Among environmental factors, presence and suitability of habitats may be a limitation for population regeneration (ERIKSSON \& EHRLÉN, 1992; TURNBULL \& al., 2000; CLARK \& al., 2007). In the context of maintenance of small populations (CAUGHLEY, 1994), fine scale field surveys will aim to investigate which microhabitats constitute suitable sites for regeneration (GRUBB, 1977). Such information, which is not revealed by coarser scale approaches, is crucial to set priorities for habitat management and conservation of endangered species.

In this study, we examine the habitat suitability of a rare perennial plant by ordination of a multivariate data set collected in several small populations across local environmental gradients. The study species is Armeria arenaria (Pers.) Schult. (Plumbaginaceae), a small perennial polycarpic plant, sparsely distributed from the Southern Alps to the Mediterranean where several rare sub-species occur in nutrient-poor and/or abiotically harsh environments (BAUMEL \& al., 2009). On the rocky crystalline coastline of South-East France, A. arenaria is the keystone species of a halophilous plant community included into the Red book of threatened plant communities of France (GÉHU, 1991). This plant and its habitat are vulnerable along the rocky coasts because of their restricted distribution and risks associated with urbanization, human trampling (recreation activities) and competition induced by invasive plants, notably Carpobrotus sp. (Aizoaceae) (SuEHS \& al., 2001).

To assess habitat suitability for Armeria arenaria, the pattern of plant community diversity and abiotic variables were integrated into a single "Outlying Mean Index analysis" (OMI; DOLÉDEC \& al., 2000) and compared with abundance and juvenile frequency in local groups of individuals of $A$. arenaria. To test the reliability of results acquired in a single year (2007), a second census was conducted three years later.

\section{Material and methods}

\section{Study species}

The genus Armeria Willd. is composed of small perennial species, occurring mainly in the Mediterranean region. In France 21 Armeria taxa occur, with 16 in the Mediterranean region. Armeria is characterized by a rosette vegetative system, capitulate inflorescence and a dimorphic reproductive system (LLEDO \& al., 1998). Most populations are composed of obligate outcrosses due to a self-incompatible system (BAKER, 1966; VeKEMANS \& al., 1990). The seeds are adapted to wind dispersal, but hairs on the calyx enable the calyx with the fruit to be attached to animals or socks (PHILIPPE \& al., 1992). Armeria species may live many decades (SILVERTOWN \& al., 2001), and along the coastline, individuals of $A$. arenaria have been reported to live at least 20 years (Youssef $\&$ al., 2009).
In our study area, Armeria is represented by $A$. arenaria subsp. bupleuroides (Godr. \& Gren.) Greuter \& Burdet, a south-eastern France endemic forming small and patchy populations situated in extreme environments and vulnerable habitats (BAUMEL \& al., 2009).

\section{Study sites}

This study was done on two peninsulas, Cap Lardier and Cap Taillat, located in the southern part of the peninsula of Saint-Tropez (Var, France), a coastal area of the Maures siliceous massif in South-Eastern France (Fig. 1).

Annual precipitation (average on the 1950-2000 period $=700-800 \mathrm{~mm})$ and the Emberger's coefficient $(\mathrm{Q}=118)$ in this area are typical of the transition between the sub-humid and humid Mediterranean bioclimates; several species are characteristic of the thermo-Mediterranean belt (e.g. Chamaerops humilis L. and Euphorbia dendroides L.) (MÉDAIL \& QuÉZEL, 1996). Armeria populations are located between the halophilous zone formed by Crithmum maritimum L. and Limonium pseudominutum Erben and the siliceous matorral ("maquis") characterised by Pistacia lentiscus L., Phillyrea angustifolia L., Erica arborea L. and Myrus communis L.

The sites are on land owned by the "Conservatoire de l'Espace Littoral et des Rivages Lacustres". Sites on the Cap Lardier are managed by the Port-Cros National Park whereas the Cap Taillat sites are managed by "Espaces Naturels de Provence" (ENP). This area is a major tourist destination in Mediterranean France and the two peninsulas are highly frequented for beach activities during the summer and by hikers all year. In 1996, a census showed that 250000 persons visited the Cap Lardier (IARE, 1998), a number which is probably increasing each year.

\section{Sampling method}

We referred to "sampling site" any place where floristic and mesologic measures were recorded. Our sampling scheme considers all occurrences of Armeria arenaria in the whole study area (Fig. 1). The exhaustive census of the individuals was carried out: 42 sampling sites of $A$. arenaria were individualized, for a total of 2369 individuals. In each sampling site where $A$. arenaria is present, a floristic relevé was undertaken in a $50 \mathrm{~m}^{2}$ circular area situated approximately at the centre of the group of individuals. Moreover, within the site of study, we randomly chose 18 sampling sites where A. arenaria is absent to confront the mesologic and floristic characteristics in situations of presence or absence of the species. In the sampling sites where A. arenaria is absent, two floristic inventories were undertaken in contiguous way. The first relevé was positioned in the halophilous zone and the second is joined to the first in order to study the whole zone between the sea and the siliceous matorral, where the presence 


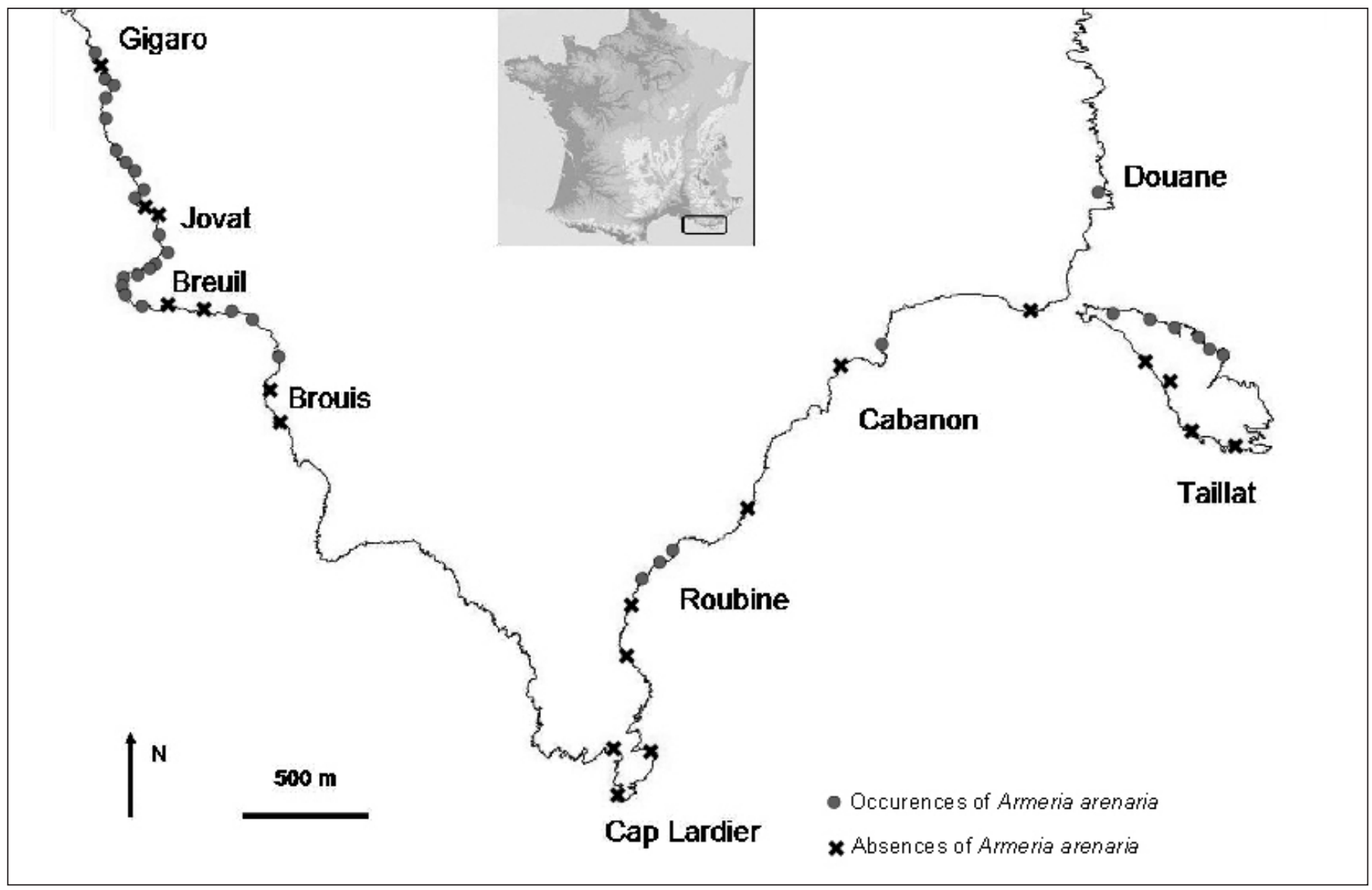

Fig. 1. - Map of the study site with location of sampling sites with and without Armeria arenaria (Pers.) Schult.

A. arenaria is potential according to MOLINIER (1954) and LAVAGNE (1984). Finally 42 relevés were done where $A$. arenaria is present and 36 where the species is absent.

Each relevé consists of a census of all the vascular plant species and measurement or estimation of the following variables: GPS coordinates, slope measure, slope orientation, mean $\mathrm{pH}$ value (average of five measures from a soil $\mathrm{pH}$ meter), granularity variables and vegetation cover. The granularity (cover of bare soil, gravels, rocks and stones), the cover of cryptogams and litters, the cover of vegetation strata [herbaceous plants $(<0.5 \mathrm{~m})$, shrubs $(0.5$ to $2 \mathrm{~m})$, high shrubs ( 2 to $4 \mathrm{~m})$, trees $(>4 \mathrm{~m})$ ] were estimated according to five classes : (1) $<10 \%$, (2) $10-25 \%$, (3) $25-50 \%$, (4) 50 $75 \%$ and $(5)>75 \%$. All relevés of the first census were performed between March and June of 2007 (Youssef \& al., 2009), a period allowing the identification of a maximum number of plant species.

Methods and results on the demographic structure of A. arenaria populations in the study site are described in Youssef \& al. (2009). Here we estimate demographic data based on the abundance (total number of individuals and frequency of juveniles). Juveniles are defined by a tuft diameter less than $40 \mathrm{~mm}$, a size threshold chosen because under this limit we never observed individuals with flowering stems. Three years later, in May 2010, the census of individuals and juveniles in each sampling site was repeated to test our inferences about habitat suitability.

\section{Floristic data analysis}

The floristic table contained 78 relevés ( 42 with $A$. arenaria and 36 without), and 104 vascular plant species. Rare species (frequency $<2 \%$ ) were removed. In order to characterize the plant community associated with $A$. arenaria, a biological spectrum of Raunkiaer's growth-forms (RAUNKIAER, 1934) and a demographic spectrum of Grime's demographic strategies (GRIME, 1974) were based upon the list of plant species for all of the sampling sites where A. arenaria is present. 


\section{OMI analysis}

Ordination techniques investigate multivariate data and allow correlating occurrences and ecological factors. They are indeed well designed to analyse organism distribution along environmental gradients (LEGENDRE \& LEGENDRE, 1998). Among available multivariate techniques, DOLÉDEC \& al. (2000) demonstrated that OMI is suited for the investigation of multidimensional niche breadths in the case of strong limiting factors. OMI analysis has been used to address the niche-habitat differentiation of plant species (e.g. CHOLER \& Michalet, 2002; Tsiftsis \& al., 2008; Youssef \& al., 2011). The construction of the ordination diagrams of OMI analysis is based on the coupling of a the table of normalized environmental variable analysed by a PCA (Principal Components Analysis) and a floristic table transformed into a specie's profile table. The total inertia (variance) given by OMI analysis is a measure of how the environmental variables separate the ecology of each species. The distance of the gravity center of a species in the OMI scatterplot to the origin of the diagram is a measure of the habitat marginality of this species (DOLÉDEC $\&$ al., 2000). Species that obtain high OMI indices (marginality indices) therefore have marginal niches (i.e., they occur in an atypical habitat in the study area), and those that obtain low OMI indices have non-marginal niches (i.e., they occur in typical habitats in the study area). The final scatterplot of OMI shows simultaneously the sampling sites and the gravity centers of species. In this scatterplot species located near the origin have non-marginal niches within the study area whereas species situated near the periphery have marginal niches.

Here, OMI analysis (ADE4 package, R software (R DEVELopment Core Team, 2009)) was used (i) to address the question of niche separation and species distribution along environmental gradients of the study area and then (ii) to infer habitat suitability for $A$. arenaria. The niche-habitat differentiation of A. arenaria and its habitat limits are therefore estimated relative to the mean habitat conditions used by all species in the study area. Spearman "Rho" correlation coefficients between the environmental variables and the two first OMI axes were computed and their significance tested with the Spearman rank test ("cor.test" function, STATS packages, $\mathrm{R}$ statistical software). Some species were displayed on the OMI scatterplot to show how plants were differentiated in the ecological space.

\section{Habitat suitability assessment}

The log of abundance and the frequency of juveniles were mapped on the OMI scatter plot to infer habitat suitability for A. arenaria. The log of abundance was used for improving the graphical display. Secondly, the Spearman "Rho" correlation coefficient (Stats package, R 2.7.2) was computed between abundance, frequency of juvenile, the OMI axes and the variables. A non-parametric Spearman rank test and the "Rho" coefficient were chosen because most of the variables such as vegetation cover or granularity were estimated and regarded as not quantitatively measured data.

To examine the reliability of our inferences about habitat suitability, Pearson correlation was also conducted on abundances between 2007 and 2010. A strong positive correlation between the two census would indicate that habitat suitability was well predicted within the temporal framework of our study. In the latter analyses, data from sampling sites lacking $A$. arenaria were excluded.

\section{Results}

\section{Floristic structure}

A total of 104 plant species (frequency $>2 \%$ ) were recorded over all the sampling sites. The spectrum of Grime's demographic strategies indicate that the plant species associated with $A$. arenaria are mainly those characterised by a "stress-tolerant-ruderal" strategy (SR: 55\%) and, to a lesser extent, the "stress-tolerant" strategy (S: 19\%). The growth form spectrum of Raunkiaer show that the plant community associated with $A$. arenaria is mainly represented by therophytes (37\%), hemicryptophytes $(29 \%)$ and chamaephytes $(20 \%)$.

\section{Niche-habitat limits}

The result of the OMI analysis allows the identification of two axes accounting for $36 \%$ and $29 \%$ of the total inertia (Fig. 2). The first axis organizes the sampling sites according to topographic variables such as the slope and the slope orientation. This axis determines also a transition from an herbaceous layer to a tree layer (from the left to the right). The second axis was mainly explained by trees, shrubs and herbaceous covers and by the rocky cover: it could be summarized as the environmental gradient existing between the sea (abundance of rocky cover) and the matorral (Fig. 2a). Moreover, a negative correlation exists between tree and shrub cover and soil $\mathrm{pH}$, which varies between 3.5 and 7 . The $\mathrm{pH}$ value is negatively correlated with the first and second axes (Table 1; correlations and weights of the variables are also given in Table 1).

The local niche-habitat limits of $A$. arenaria were clearly established by the OMI ordination diagram (Fig. 2b), since most occurrences of $A$. arenaria are on the left of the first axis. Armeria arenaria occurs in the salt tolerant plant community, mainly represented by small perennial species, with a value of soil $\mathrm{pH}$ ranging from 5 to 7 . This community is mainly observed on northern and western orientations of the slopes. On the other hand, A. arenaria is absent from sampling sites with a strong slope, dominated by shrubs or trees, 


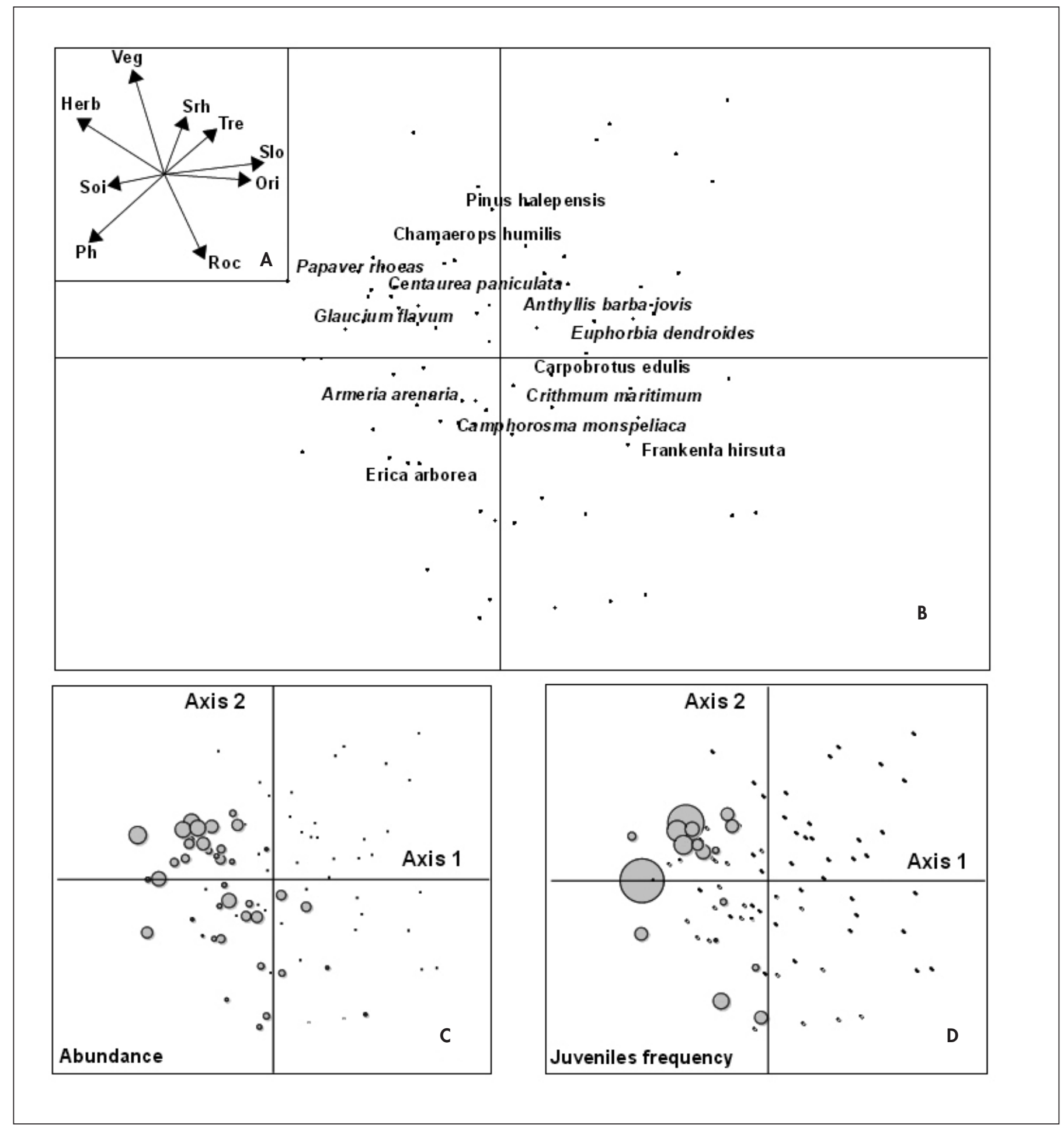

Fig. 2. - Ordination diagrams of the Outlying Mean Analysis (OMI). A. Scatter plots of 78 sampling sites along OMI axis 1 and axis 2 with some plant species displayed [Slo: slope; Ori: orientation of the slope; Roc: rock cover; Ph: mean soil pH value; Soi: bare soil cover; Herb: herbaceous cover; Veg: total vegetation cover; Srh: shrubs cover, Tre: tree cover]; B. Sampling sites with Armeria arenaria (Pers.) Schult. are indicated with a symbol size proportional to the log of abundance measured in 2007 ; C. Sampling sites with $A$. arenaria are indicated with a symbol size proportional to the juvenile frequency measured in 2007 ; D. Dots are for sampling sites without $A$. arenaria. 
Table 1. - Sperman rank correlation "Rho" values between the variables, the first two axes of the OMl analysis and abundance or juvenile frequencies of Armeria arenaria (Pers.) Schult.

\begin{tabular}{|c|c|c|c|c|c|c|}
\hline & OMl axis 1 & OMl axis 2 & $\begin{array}{c}\text { Abundance } \\
2007\end{array}$ & $\begin{array}{c}\text { Abundance } \\
2010\end{array}$ & $\begin{array}{c}\text { Juveniles } \\
\text { frequencies } 2007\end{array}$ & $\begin{array}{c}\text { Juveniles } \\
\text { frequencies } 2010\end{array}$ \\
\hline Slope & $0.7^{* * *}$ & $-0.15 n s$ & $-0.05 n s$ & $-0.03 n s$ & $-0.22 n s$ & $-0.2 \mathrm{~ns}$ \\
\hline Slope orientation & $0.64 * * *$ & $-0.15 n s$ & $-0.33^{*}$ & $-0.32 *$ & $-0.2 \mathrm{~ns}$ & $-0.1 \mathrm{~ns}$ \\
\hline Bare soil cover & $-0.48 * * *$ & $0.17 \mathrm{~ns}$ & $0.07 \mathrm{~ns}$ & $0.09 \mathrm{~ns}$ & $-0.23 n s$ & $-0.25 \mathrm{~ns}$ \\
\hline Total vegetation cover & $-0.23^{*}$ & $0.88 * * *$ & $0.6 * * *$ & $0.55^{* * *}$ & $0.3^{*}$ & $0.19 \mathrm{~ns}$ \\
\hline Herbaceous cover & $-0.6 * * *$ & $0.46 * * *$ & $0.55^{* * *}$ & $0.46 * * *$ & $0.17 \mathrm{~ns}$ & $0.23 \mathrm{~ns}$ \\
\hline Mean soil pH value & $-0.36 * * *$ & $-0.45^{* * *}$ & $-0.45^{* *}$ & $-0.34^{*}$ & $-0.08 n s$ & $0.05 \mathrm{~ns}$ \\
\hline OMI axis 1 & & & $-0.45^{* *}$ & $-0.48 * * *$ & $-0.42^{*}$ & $0.35^{*}$ \\
\hline OMI axis 2 & & & $0.61 * * *$ & $0.53 * * *$ & $0.41 * *$ & $0.25 \mathrm{~ns}$ \\
\hline
\end{tabular}

${ }^{* *}=p<0,001 ;{ }^{* *}=p<0,01 ;{ }^{*}=p<0,05 ;$ ns = non-significant; na = non assessed

and where the $\mathrm{pH}$ values range from 3.5 to 5 . In conclusion, OMI ordination diagram (Fig. 2 and Table 1) demonstrate that the habitat of $A$. arenaria is correlated to soil availability (soil variable) in open flat places (vegetation cover and slope variables) and northern or western slopes (orientation variable).

\section{Variation of abundance and juvenile frequency within the habitat}

Nevertheless, the habitat of $A$. arenaria is not homogeneous because of different places corresponding to different habitat suitability. The sampling sites with a rather large number of individuals and the highest juveniles frequency (in top and on the left of Fig 2c, d) are located on gentle slopes characterised by a finely grained upper soil substrate and a high herbaceous plant cover (see also Table 1). These sampling sites are situated on the eastern coast (Cape Taillat and Roubine), and contained a total of 1566 individuals distributed across 10 sampling sites in 2007.

Sampling sites defined by a rather small number of individuals (in bottom and on the left of Fig. 2) are situated along the western part (from Gigaro to Brouis) of the study area. These sampling sites are characterized by low frequency of bare soil and herbaceous plants and a high frequency of rocks (see also Table 1). They are also characterized by low juvenile frequency (Fig. 2d). These sampling sites contained in 2007 a total of 803 individuals distributed in 32 sampling sites.

\section{Temporal variation of abundance}

The two censuses reported similar numbers of individuals: 2350 in 2010 compared to 2369 in 2007 . Moreover the mean number of individuals per sampling site were not significantly different (mean in $2007=56.4$, mean in $2010=55.9, p$ value of a student test $=0.98$, t.test function Stats package, R 2.7.2). We did not observe any extinction of sampling sites nor the appearance of plants at any sampling site where it was observed to be absent in 2007 during the census of 2010. It is not surprising therefore that the Pearson correlation test reported a strong and positive association between the abundance of the two census $(r=0.96, p<0.001)$. Moreover the correlation between abundances and environmental variables established in 2007 are similar to the ones of 2010. This result indicates that correlations between habitat and abundance estimated for A. arenaria in 2007 were still valid in 2010.

The mean number of juveniles by sampling site did not significantly differ between the two census (mean in $2007=9$, mean in $2010=16, p$ value of a student test $=0.27$, t.test function Stats package, $R$ 2.7.2). Juvenile frequency was negatively correlated to rock cover in 2007 and 2010 (Table 1).

\section{Discussion}

In the Mediterranean region, the most threatened plant species are situated in open habitats at low altitude (i.e. rocky grasslands, wetlands and/or coastal ecosystems) exposed to increasing and strong human impacts (MéDAIL \& VerLaQue, 1997; VerLAQUE \& al., 2001; MÉDAIL, 2008). Located within the Côte d'Azur region, which is highly threatened by urbanization and land-use changes, the peninsulas of Cap Lardier and Cap Taillat constitute significant reservoirs of biodiversity due to their inclusion within sites now owned by the Conservatoire du Littoral. This area contains an important number of rare or threatened plants, including fifteen protected species 
by law in France (Olivier \& al., 1995; LACOSSE \& ABoucaYA, 2005). Nevertheless, several disturbances persist in this protected area, notably increased trampling induced by recreational activities and the negative consequences of invasion caused by Carprobrotus spp. and Opuntia spp. along the coast.

Although we observed that the characteristic plant species associated with $A$. arenaria, according to MolinIER (1954) and LAVAGNE (1984), remain rather frequent on the entire studied zone, our study also revealed the presence of some ruderal species, such as Chrysanthemum coronarium L., Lobularia maritima (L.) Desv., Senecio vulgaris L. and Silene vulgaris (Moench) Garcke, and invasive species such as Opuntia spp. or Carpobrotus spp. Beyond this coarse statement, the integration of abundance of a focus species with floristic and habitat variables revealed important patterns for conservation and management priorities at finer scale. Abundance variation within the OMI diagram (Fig. 2c) revealed that habitat suitability for Armeria arenaria is dependent of the availability in fine soil, a soil $\mathrm{pH}$ value above 5 , a reduced woody and rocky cover and flat or gentle slopes. It is indeed possible to distinguish three habitats for A. arenaria: unsuitable, small abundance, and high abundance. They are related with three plant communities: matorral and forest, salt-tolerant rocky grassland and meso-xerophilous grassland respectively. The absence of any population increase or decrease and the strong positive correlation (Table 1) between the two demographic surveys performed in 2007 and 2010, ensures that our inferences about habitat suitability for $A$. arenaria are reliable at least for the temporal scale of a few years.

The highest values of abundance and juvenile frequency are found in the mesoxerophilous grassland habitat type (e.g. sampling sites of Cap Taillat, but also one sampling site of Roubine site). The availability of fine soil elements may represent an important factor of habitat suitability for $A$. arenaria. Moreover flat slopes with bare soils can enhance local dispersion of diaspores and therefore indirectly favour seedling recruitment. These situations are thus priority conservation sites for $A$. arenaria as they may represent habitat of high demographic regeneration in the study area. A recent study on A. caespitosa L., a high mountain iberic endemic, demonstrated also the importance of microsite availability for seedling emergence and survival (GARCÍA-CAMACHO \& al., 2010). This latter study underlined the positive effect of bare soil cover and the negative effect of grass and rock covers, and these results are therefore convergent with our inferences for $A$. arenaria.

Although it is not supported by our correlation analysis (Table 1), shrub cover development may also have a negative effect on the abundance of $A$. arenaria. Indeed historical records reported $A$. arenaria in the extremity of the Cap Lardier (LAVAGNE, 1984), where it has now disappeared (Youssef \& Baumel, pers. comm.), perhaps as a consequence of the colonization of the area by invasive species such as Anthyllis barba-jovis L. and Euphorbia dendroides L. This observation, the results presented here and elsewhere for Armeria arenaria (Youssef \& al., 2009), and also for A. maritima (LeFEVBre \& Chandler-Mortimer, 1984) and A. caespitosa (GarcíaCAMACHO \& al., 2010), suggest that the local population viability of $A$. arenaria is particularly related to the availability of open suitable places for seedling recruitment.

In contrast with the habitats associated with evidence of recent regeneration, rocky areas are inhabited by old individuals of A. arenaria anchored within cracks of the bed-rock. This is particularly the case of the western part of the Cap Lardier where it is hypothesized that the soil may have been eroded by human trampling (YousseF \& al., 2009). Admitting that perennial plants can persist over long unsuitable periods thanks to the long duration of their life cycle (SILVERTOWN \& al., 2001; García \& ZAMORA, 2003; Nicolè \& al., 2005; ANDRIEU \& al., 2007), the oldest isolated individuals, should be preserved, as they store reproduction potentiality for future more suitable conditions. This is particularly relevant if protection from trampling could be considered as a key management priority in such protected areas threatened by high touristic pressures. Few sampling sites situated in Gigaro are protected by fences settled by the national park. Although our study did not constitute a test of the efficiency of fences we observed that these sampling sites sheltered more juveniles than neighbouring unprotected areas.

\section{Conclusion}

Our results underline the importance of integrating finescale habitat heterogeneity into studies of habitat suitability and the need to consider both the regeneration and the persistence niches (GRUBB, 1977). Here, the plant community in which A. arenaria occurs is threatened by human trampling. Paths for tourists along the coastline should be settled to avoid zones with flat bare soils due their important role in the regeneration of small perennial plants such as Armeria. Long-term monitoring of $A$. arenaria in the study area should integrate the environmental gradient determining its local abundance and regeneration in the study area.

\section{Acknowledgements}

This research was supported by the National Park of PortCros (project $n^{\circ}$ 06-026). We thank an anonymous reviewer for helpful comments on the manuscript. 


\section{References}

Andrieu, E., J. D. Thompson \& M. Debussche (2007). The impact of forest spread on a marginal population of a protected peony (Paeonia officinalis L.): the importance of conserving the habitat mosaic. Biodivers. \& Conservation 16: 643-658.

BAKER, H. G. (1966). The evolution, functioning and breakdown of heteromorphic incompatibility systems, I. The Plumbaginaceae. Evolution 20: 349-368.

BAUMEL, A., P. AUdA, F. TORRE \& F. MÉDAIL (2009). Morphological polymorphism and rDNA ITS sequence variation of Armeria (Plumbaginaceae) in South-Eastern France. Bot. J. Linn. Soc. 159: 255-267.

Caughley, G. (1994). Directions in conservation biology. J. Anim. Ecol. 63: $215-244$.

Choler, P. \& R. Michalet (2002). Niche differentiation and distribution of Carex curvula along a bioclimatic gradient in the southwestern Alps. J. Veg. Sci. 13: 851-858.

Clark, C. J., J. R. Poulsen, D. J. Levey \& C. W. Osenberg (2007). Are plant populations seed limited? A critique and meta analysis of seed addition experiments. Amer. Naturalist 170: 128-142.

DolÉDEC, S., D. Chessel \& C. Gimaret-CARPEnTIER (2000). Niche separation in community analysis: a new method. Ecology 81: 2914-2927.

ERIKSSON, O. \& J. EHRLÉN (1992). Seed and microsite limitation of recruitment in plant populations. Oecologia 91: 360-364.

GARCÍA, D. \& R. ZAMORA (2003). Persistence, multiple demographic strategies and conservation in long-lived Mediterranean plants. J. Veg. Sci. 14: 921-926.

García-CAmacho, R., J. M. IrIondo \& A. Escudero (2010) Seedling dynamics at elevation limits: complex interactions beyond seed and microsite limitations. Amer. J. Bot. 97: 1791-1797.

GeHU, J. M. (1991). Livre rouge des phytocénoses terrestres du littoral français. Centre régional de phytosociologie, Bailleul.

GRIME, J. P. (1974). Vegetation classification by reference to strategies. Nature 250: 26-31.

GRUBB, P. J. (1977). The maintenance of species-richness in plant communities: the importance of the regeneration niche. Biol. Rev. 52: 107145.

IARE (1998). Le cap Lardier (La Croix Valmer, Var). Etat des lieux, diagnostic, propositions de gestion. Volume 1. Parc National de Port-Cros.

LACosse, P.-A. \& A. ABOUCAYA (2005). Additions à la flore des magnoliophytes, pinophytes et filicophytes du cap Lardier (Provence, France). Trav. Sci. Parc Natl. Port-Cros 21: 193-202.

LAVAGNE, A. (1984). Etude du milieu naturel-flore, phytosociologie et carte de végétation - aire du cap Lardier et cap Mimosa \& aire de la Briande. Parc national de Port-Cros.

Lefebvre, C. \& A. Chandler-Mortimer (1984). Demographic characteristics of the perennial herb Armeria maritima on zinc lead mine wastes. J. Appl. Ecol. 21: 255-264.

LEGENDRE, P. \& L. LEGENDRE (1998). Numerical ecology second english edition. Elsevier.

Lledó, M. D., M. B. Crespo, K. M. CAmeron, M. F. FAy \& M. W. Chase (1998). Systematics of Plumbaginaceae based upon cladistic analysis of rbcL sequence data. Syst. Bot. 23: 21-29.
MÉDAIL, F. (2008). Plantes du littoral. In: CRUON, R. (ed.), Le Var et sa flore, plantes rares ou protégées: 477-488. Naturalia Publications.

MÉDAIL, F. \& P. QUEZEL (1996). Signification climatique et phytoecologique de la redécouverte en France méditerranéenne de Chamaerops humilis L. (Palmae). Compt. Rend. Acad. Sci. Paris, Sér. 3, Sci. Vie 319: 139145.

MÉDAIL, F. \& R. VERLAQUE (1997). Ecological characteristics and rarity of endemic plants from S-E France and Corsica: implications for biodiversity conservation. Biol. Conservation 80: 269-281.

Molinier, R. (1954). Observation sur la végétation de la zone littorale en Provence. Vegetatio 5-6: 257-267.

Nicolè, N., E. Brzosko \& I. Till-Bottraud (2005) Population viability analysis of Cypripedium calceolus in a protected area: Longevity, stability and persistence. J. Ecol. 93: 716-726.

Olivier, L., J. P. Galland, H. Maurin \& J. P. Roux (1995). Livre rouge de la flore menacée de France. Tome I: Espèces prioritaires. Muséum National d'Histoire Naturelle, Conservatoire Botanique National de Porquerolles \& Ministère de l'Environnement.

PhilipPe, M., H. E. S. Madsen \& H. R. Siegismund (1992). Gene flow and population structure in Armeria maritima. Heredity 69: 32-38.

R DEVElOPMENT CORE TEAM (2009). $R$ : language and environment for statistical computing. R foundation for statistical computing, Vienna. [Available at http://www.R-project.org].

RAUNKIAER, C. (1934). The life form of plants and statistical plant geography. Oxford University Press.

Silvertown, J., M. Franco \& R. Perez-Ishiwara (2001). Evolution of senescence in iteroparous perennial plants. Evol. Ecol. Res. 3 : 393412.

Suehs, C. M., F. MédAIL \& L. Affre (2001). Ecological and genetic features of the invasion by the alien Carpobrotus plants in Mediterranean island habitats. In: BRUNDU, G., J. BROCK, I. CAMARDA, L. CHILD \& M. WADE (ed.), Plant invasions: species ecology and ecosystem management: 145-158. Backhuys Publisher, Leiden.

TsIFTSIS, S., I. Tsiripidis, V. KARAgIANNAKIDOU \& D. ALIFRAGIS (2008). Niche analysis and conservation of the orchids of east Macedonia (NE Greece). Acta Oecol. 33: 27-35.

TurnBull, L. A., M. J. CRAWLey \& M. ReEs (2000). Are plant populations seed-limited? A review of seed sowing experiments. Oikos 88: 225238.

Vekemans, X., C. Lefèbvre, L. Belalia \& P. J. Meerts (1990). The evolution and breakdown of the heteromorphic incompatibility system of Armeria maritima revisited. Evol. Trends Pl. 4: 15-23.

Verlaque, R., MéDAil, F. \& A. Aboucaya (2001). Valeur prédictive des types biologiques pour la conservation de la flore méditerranéenne. Compt. Rend. Acad. Sci. Paris, Sér. 3, Sci. Vie 24: 1157-1165.

Youssef, S, A. BAumel \& F. MÉDAIL (2009). Structure démographique d'Armeria arenaria (Pers.) Schult. (Plumbaginaceae), une espèce bioindicatrice de l'état de conservation de la flore littorale des Maures (Var, France). Candollea 64: 245-256.

Youssef, S., A. Baumel, E. Véla, M. Juin, E. Dumas, L. Affre \& T. TATONI (2011). Factors underlying the narrow distribution of the Mediterranean annual plant Arenaria provincialis (Caryophyllaceae). Folia Geobot. 46: 327-350. 